чистотою та дзвінкістю кольорів: синій кобальт, жовті , помаранчеві кадмії - символ оптимізму, надії та добра. Разом з тим, з явився чистий білий колір площин, що символізує Віру та Любов, перевагу Духу над матерією.

Отже, зробивши короткий огляд творчості лише деяких митців Прикарпаття можемо прослідкувати розвиток чи радше продовження традицій символізму у малярстві, що грунтується на кращих надбаннях мистецтва різних епох. Допоки людина, митець буде тікати від сірої буденності чи солодкої реальности, доти шукатиме нових образів, створюючи мову знаків та символів не буквальних, проте багатозначних і утаємничених, завдяки чому образи набувають ознак недовимовленості й загадковості, закликаючи глядача до співтворчості в їх тлумаченні.

Звичайно, дослідження символізму в образотворчості прикарпатських мистців потребує подальших кроків до вивчення, адже список авторів та мистецтво їх символіки $\epsilon$ набагато ширшим.

\title{
Література:
}

1. Михайло Фіголь. Альбом / упоряд. Олесь Фіголь. Львів: Кварт, 2018. $312 \mathrm{c}$.

2. Павліченко Н. Мова символів. День. - 2019. - 10 жовтня (№ 185). - C. 12. URL: https://day.kyiv.ua/uk/photo/mova-symvoliv

DOI https://doi.org/10.30525/978-9934-26-178-7-35

\section{АБСТРАКЦІОНІЗМ ТА РЕАЛІЗМ У СТИЛІСТИЦІ СТАНКОВОГО ЖИВОПИСУ КИТАЮ (НА ПРИКЛАДІ ДРУГОЇ ПОЛОВИНИ ХХ СТОЛІТТЯ)}

\author{
Хуан Сін \\ аспірант кафедри методологій крос-культурних практик \\ Харківська державна академія дизайну і мистеитв \\ м. Харків, Украӥна
}

За період останніх десятиліть XX століття в Китаї головний інтерес в образотворчому мистецтві був пов'язаний із течіями XX століття, які довгий час були під забороною. Проникнення нових течій розпочалося через теоретичне осмислення. «Живопис шрамів» та «Сільський реалізм» виявилися першим кроком на шляху розкриття нових 
горизонтів для китайських художників. Бурхливі дискусії, які не стихали наступні п'ять років, вибухнули навколо статті «Про красу форми» У Гуаньчжуна. Художник у вільній формі висловлював свої думки про значення форми у мистецтві, як одного із способів служіння красі [1, c. 33].

Для більшості митців у той період було очевидним, що неможливо більше звертатися лише до реалістичних тенденцій, так і У Гуаньчжун говорив про посилення образного початку, називаючи це натхненням i духовною наповненістю, свіжістю першого враження. Як приклад, він наводив творчість французьких імпресіоністів, які були близькі до його сприйняття цінності образотворчого мистецтва. Важливо відзначити, що імпресіоністичний метод тривалий час після культурної революції, мав велику популярність. Але найголовніше у статті майстра було твердження, що «правдивість» у мистецтві не дорівнює ступеню реалістичності зображення. Наслідком цього у статті йдеться про більшу значущість форми, тобто питання «як зображати?» було важливішим, ніж «що зображати?» [2, с. 44].

У мистецтві Китаю даного періоду ці погляди проявляють себе у збільшенні зацікавленості до вивчення та милування більш розширеною та вільною кольоровою гамою, фактурою, пошуку нових композиційних побудов. Інші художники (зокрема Пен Де) підтримують міркування У Гуаньчжуна про естетичну цінність мистецтва, роблячи висновок, що суть мистецтва виключно у собі («мистецтво мистецтва»). Стаття Гуаньчжуна мала велике значення для усвідомлення нових завдань у китайському мистецтві $1970-\mathrm{x}$ років. Для розуміння новаторства поглядів, озвучених художником, необхідно взяти до уваги особливості творчого методу китайських майстрів [3, с. 201].

Діяльність художників ділилася на «творчу», цим терміном позначалося створення витворів для виставок, музеїв та виставок глядачам, та «тренувальну», що складалася 3 натурних замальовок та роботи на пленері. Остання була підготовчим етапом під час створення творчих витворів. Звернемо увагу, що обидва терміни наводяться у дослівному перекладі з китайської мови. У Гуаньчжун бачив у цьому розділенні перешкоду для роботи художників. Метою тренувальної практики було відпрацювання техніки, необхідної для об'єктивної та точної передачі дійсності художником, вона передбачала фактично байдуже копіювання об'єктів, і, таким чином, робота 3 формою в живописі відбувалася лише у форматі вдосконалення композиції та реалістичних прийомів, а «безсюжетне» малювання з натури не вважалося творчим процесом. У Гуаньчжун у статті пропонує скасувати подібне розділення. Художня діяльність - це єдине ціле, креативність і техніка - це не більше, ніж дві 
концепції, які можуть бути застосовані для осмислення одного і того ж $з$ різних боків... Насправді, питання «як зображати» не в меншій мірі $\epsilon$ предметом невтомного пошуку багатьох художників.

У Гуаньчжун бачить головну ідею у передачі свіжого враження, того, що схвилювало художника, коли він працював з натури, а головною перешкодою цього бачення стає саме прагнення максимально реалістично зобразити побачене, керуючись не своїм сприйняттям, а правилами перспективної побудови та створення ілюзорності у картині. Ідея правдивості у мистецтві не пов'язана для художника 3 його тотожністю реальності.

С точка зору, що ця ідея у Гуаньчжуна сприйнята ним від імпресіоністів, однак, цілком очевидно, що на його творчість, а, як наслідок, і на погляди, значний вплив зробив досвід експресіонізму. Це один із ключових моментів у розумінні мистецтва Китаю після культурної революції. Довгий час у дослідженнях китайських аспірантів фігурувало здійснення аналізу творів мистецтва, що виявляють вплив радянської та російської шкіл живопису. Це було пов'язано зі спробою зв'язати культурну спадщину двох країн. Пізніше почали з'являтися роботи, які висвітлюють зв'язок китайського мистецтва та імпресіонізму.

Логічним $\epsilon$ те, що, отримавши доступ до спадщини західного мистецтва, багато майстрів були зачаровані творчістю французів. Однак, на даний момент через сорок років після закінчення культурної революції стає очевидним, що потужним поштовхом до розвитку сучасного мистецтва стає експресіонізм. В даному випадку, буде помилково вказувати зв'язок У Гуаньчжуна з імпресіоністами і не вказати на його відкриті зіткнення з експресіонізмом. Безпосередність сприйняття, що подібна до дитячої творчості, про яку пише у статті художник, куди сильніше пов'язана 3 досвідом «несвідомого листа», ніж здається на перший погляд. Він згадує і про важливість суб'єктивного мистецтва, i інстинктивного. Як наслідок із вищесказаного можна стверджувати, що тепер у мистецтві Китаю першорядною стає проблема «як зображати», а не «що зображати», тому саме така назва статті «Краса форми». Цією статтею Гуаньчжун зміг сформулювати початок етапу в мистецтві Китаю, коли пріоритетним у розумінні цінності живопису, та й усього образотворчого мистецтва стає естетична складова, виражена в зовнішній формі. Також це розривало і зв'язок мистецтва з ідеологією та політикою, що ще десятиліттям раніше було не просто неможливим, а й злочинним.

Тут можна згадати, як неприйнятих художників не просто посилали на примусові важкі роботи у віддалені селища, а й забороняли 138 
працювати. Ця стаття така важлива у розкритті полеміки ще й тому, що вона опинилася на верхівці зміни двох періодів. Один із яких вимагав від будь-якої суспільної творчості приносити користь суспільству, закликати до громадянських цінностей, тоді як нові часи проголошували естетичні функції мистецтва, такі, як творчість заради краси. Стаття була прийнята одноголосним схваленням, прихильники реалістичного мистецтва піддали жорсткій критиці естетичну концепцію У Гуаньчжуна.

Критика викликала хвилю відповідей художників, які прагнули підтримати очевидну ідею У Гуаньчжуна. Пен Де у статті «Застосування краси - єдина функція образотворчого мистецтва» привертає увагу до базових цінностей образотворчого мистецтва, таких як відсутність практичної, матеріальної користі, відсутність навчальної складової в образотворчому мистецтві. Йдеться про те, що неможливо отримати нову практичну інформацію, оскільки мистецтво не генерує нової інформації. А так як єдиною існуючою рисою мистецтва $є$ «краса», то й естетична функція стає єдиною можливою для мистецтва. Але Пен Де розрізняє функції та цілі мистецтва. Серед цілей він виділяє можливість мистецтва викликати людські емоції засобами форми. Безумовно, Пен Де занадто звужує цілі та засоби мистецтва, щоб посилити важливість своїх тверджень. Неможливо не відзначити, що предмет зображення теж стає важливою складовою емоційного впливу, що у перше десятиліття після культурної революції проявилося у «живописі шрамів». Так було зрозуміліше, ясніше і давало змогу здійснити поступовий перехід $[4$, c. $84-85]$.

Однак, важливо загострити увагу на тому, що становлення та розвиток станкового мистецтва в Китаї в XX столітті не може бути пов'язане лише з реалістичними тенденціями. Саме з У Гуаньчжуном пов'язане й нове ставлення до абстрактних форм. У своїй статті «Про абстрактну красу» він пише, що абстрактна краса - це ядро краси форми, а людська любов до краси форм та абстрактної краси інстинктивна. У цьому абстрактне мистецтво осмислюється 3 двох сторін: $з$ одного боку, як власне спосіб пізнання деяких абстрактних законів краси, 3 іншого боку, як результат вивчення цих законів, втілений у витворах мистецтва. Абстракціонізм як метод передбачає пошук та вилучення 3 реально існуючих об'єктів закономірностей, принципів, факторів, що створюють відчуття прекрасного: певних поєднань кольорів, контрастів, форм, ліній, ритму, які, з'єднуючись, свідомо сприймаються нами як красиві, породжують певні образи та настрої. Чому одні квіти та дерева здаються нам естетичнішими, ніж інші? Чому полотна традиційного китайського живопису ми оцінюємо по-різному, хоч у сюжетному плані 
вони практично ідентичні? Художник помічає, що $є$ універсальні, загальні закони краси, всі вони мають бути абстрактними, сприймаються як усвідомлено, і несвідомо. Абстрактне мистецтво, зберігаючи цю універсальну красу, одночасно стає ще й способом максимальної передачі суб'єктивного світу художника, його підсвідомості, пов'язаного 3 індивідуальним досвідом та переживаннями, тобто способом висловлювати невимовне, те, що не може бути виражене в словах. Художники в абстрактних композиціях передають невербальний зміст, який зчитується глядачами за допомогою їхнього несвідомого досвіду.

\title{
Література:
}

1. У Гуаньчжун. Хуэйхуа дэ синши мэй (Красота формы в живописи). Мейшу. 1979. № 5. С. 35-42.

2. Титаренко М. Духовная культура Китая. Искусство. Москва : Восточная литература, 2008. $876 \mathrm{c.}$

3. Неглинская М. А. Современное изобразительное искусство. Москва : «Наука», 2006. 1340 с.

4. Завадская Е. В. Ци Байши. Москва : Искусство, 1982. 230 с.

\section{DOI https://doi.org/10.30525/978-9934-26-178-7-36}

\section{ФОРМУВАННЯ ЦІНОВОЇ ПОЛІТИКИ ТВОРІВ ГРАФІКИ У ХІХ СТОЛІТТІ НА ГОЛАНДСЬКИХ МИСТЕЦЬКИХ ПЛАТФОРМАХ}

\author{
Черкашина Н. О. \\ аспірантка кафедри мистецтвознавчої експертизи \\ Національна академія керівних кадрів культури та мистецтв, \\ головний судовий експерт \\ Харківський науково-дослідний експертно-криміналістичний иентр \\ Міністерства внутрішніх справ \\ м. Харків, Україна
}

При дослідженні графічних робіт з колекції Харківського художнього музею виникла необхідність у вивченні представлення акварелей на мистецькому ринку Європи у XVIII століття, процесу формування цін відносно попиту та пропозицій акварелей у порівнянні з олійним живописом. Робота була проведена на опрацюванні архівних даних 